\title{
Cell Therapy in Demyelinating Diseases
}

\author{
Claire Rice, Christopher Halfpenny, and Neil Scolding \\ University of Bristol Institute of Clinical Neurosciences, Department of Neurology, Frenchay Hospital, Bristol, BS16 1LE, \\ United Kingdom
}

\begin{abstract}
Summary: Multiple sclerosis presents particular and serious problems to those attempting to develop cell-based therapies: the occurrence of innumerable lesions scattered throughout the CNS, axon loss, astrocytosis, and a continuing inflammatory process, to name but a few. Nevertheless, the limited and relatively focused nature of damage to oligodendrocytes and myelin, at least in early disease, the large body of available knowledge concerning the biology of oligodendrocytes, and the success of experimental myelin repair, have allowed cautious
\end{abstract}

optimism that therapies may be possible. Here, we review the clinical and biological problems presented by multiple sclerosis in the context of cell therapies, and the neuroscientific background to the development of strategies for myelin repair. We attempt to highlight those areas where difficulties have yet to be resolved and draw on a variety of more recent experimental findings to speculate on how remyelinating therapies are likely to develop in the foreseeable future. Key Words: Multiple sclerosis, remyelination, stem cells, cellular therapy, demyelination.

\section{INTRODUCTION}

Within the past year or so (formal publication is awaited), the first patients with multiple sclerosis (MS) have, by way of preliminary clinical experiment, received intracerebral implants of cells, in the hope that these (autologous Schwann) cells would effect myelin repair (http://www.myelin.org/12082003.htm). Early and informal indications suggest that proof of efficacy is lacking, but there is a drama underlying this work: reparative cell therapy in multiple sclerosis has finally begun its journey from laboratory to clinic.

What has been the experimental rationale for this work, and, no less important, what is the future of cell therapy in multiple sclerosis? Does it lie with Schwann cells, or with stem cells, with other glia or none? Here we propose that, while serious and substantial clinical and biological problems remain to be solved, remyelination treatments by cell-based therapy represent an approachable challenge, offering a realistic prospect of successful implementation for the current generation of patients with multiple sclerosis.

Address correspondence and reprint requests to N. J. Scolding, Institute of Clinical Neurosciences, Frenchay Hospital, Bristol, BS16 1LE, UK. E-mail: N.J.Scolding@bristol.ac.uk.

\section{THE CLINICAL SCIENTIFIC BACKGROUND TO CELL THERAPY FOR DEMYELINATION}

The complexity of the CNS poses daunting challenges to reparative medicine. Not for nothing did Cajal coin the immortal if lugubrious phrase "everything may die, nothing may be regenerated," and affirm the perception that the brain has traded flexibility in response to damage, and a capacity for functional, regenerative repair, for prodigious sophistication and complexity. In the context of this challenging background, there are, however, three good reasons to believe that demyelinating diseases such as multiple sclerosis might have significant advantages over many other CNS disorders in their inherent eligibility for cell therapies.

The first is that, despite the valuable concentration on axon loss in multiple sclerosis in recent years, it remains primarily a demyelinating disease. Axon loss undoubtedly occurs earlier in the course of MS than previously believed, and is more than likely to represent the principal pathophysiological cause of disability in chronic progressive disease, but none of the recent experimental, imaging, or neuropathological studies have challenged the concept that disease processes in MS are primarily directed against oligodendrocytes and/or myelin, and that axons are relatively spared until late disease. ${ }^{1,2}$ The importance of considering the mechanism of axon loss is addressed below, but the key implication of the primary 


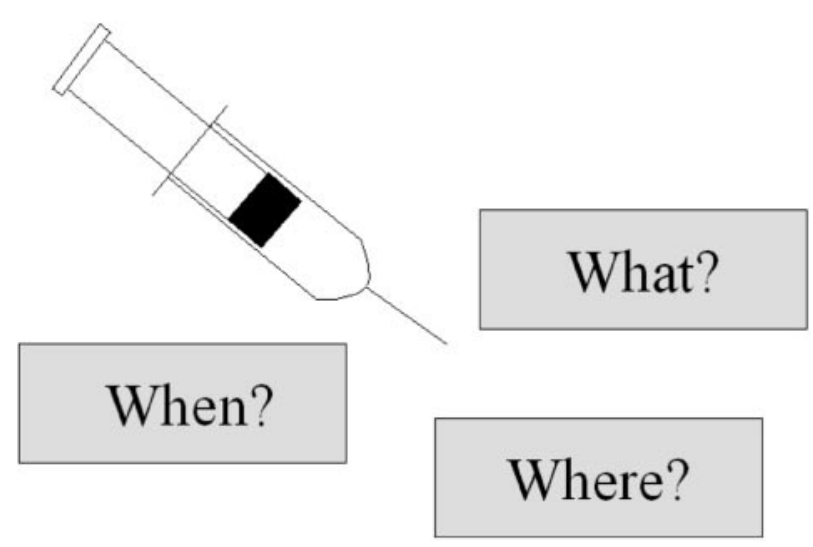

FIG. 1. Questions to be considered in the development of reparative cell therapy.

targeting of myelin in MS is that, in the main, axon pathways remain intact. Cell therapies therefore aim "only" to reinvest axons with myelin, rather than address the almost overwhelming challenge presented by other neurological diseases: that of re-establishing connectivity in highly complex but fragmented axonal circuitry.

The second positive feature of MS, in terms of developing cell therapies, is found in the clear evidence of spontaneous if partial myelin repair in multiple sclerosis. $^{3-6}$ The aim of cell therapies thus ceases to be the artificial imposition of a repair phenomenon de novo, and becomes one of enhancing or supplementing a spontaneous process. How this might be done must depend on a better understanding of the clinical biology of the disease, including the reasons why endogenous repair is not more successful, and how these limitations can be overcome.

Thirdly, there is now available a very large body of experimental evidence, employing a wide variety of animal models of demyelination and a range of sources of remyelinating cells, collectively providing proof of principle: cell therapy can, without question, achieve successful remyelination. Thus, implanted dissociated rat Schwann cells remyelinate the rodent $\mathrm{CNS},{ }^{7,8}$ and can restore normal conduction ${ }^{9}$; transplantation of purified oligodendrocyte lineage cells $\mathrm{s}^{8,10-15}$ or cell lines ${ }^{12,16,17}$ likewise achieves myelin repair, accompanied by improved conduction ${ }^{18}$ and also demonstrable functional recovery. ${ }^{19}$ Olfactory ensheathing cells (OECs), upon transplantation into lesions containing demyelinated axons, also lay down (Schwann cell-like) myelin. ${ }^{20,21}$ Rodent embryonic stem cells and neural stem cells expanded from adult rodent brain both possess significant remyelinating potential. ${ }^{22-25}$ Adult bone marrow also contains stem cells with neurogenic (and other) potential: these cells too, upon injection, are associated with successful myelin repair. ${ }^{26,27}$

\section{THE REMAINING OBSTACLES TO DEVELOPING EFFECTIVE CELL THERAPIES IN MS}

Against this positive experimental and pathological background to therapeutic remyelination in MS, why is it that cell therapies, or at least clinical experimental therapeutic trials, are not already widespread in this disease? What are the significant remaining hurdles, and how serious are they? What still needs to be done to develop at least potentially effective interventions? At least four significant problems readily suggest themselves: each will be briefly considered (FIG. 1).

\section{The timing of implantation: early or late?}

The firstprinciple in any new therapeutic endeavor must always remain "first, do no harm." In late MS, when progressive disability is established, and hope of spontaneous recovery extinguished, the possibility of doing damage or at best compromising spontaneous repair is remote. However, compelling arguments must be offered if the early exhibition of any potentially hazardous intervention in MS is to be justified; at this stage, little disability is present and therefore there is much to lose, and the natural history is such that some patients will never develop significant disability. In addition, implanting cells into early lesions exposes remyelinating glia, and their new myelin, to ongoing inflammatory activity. Concurrent use of potent immunosuppressive agents, required in any case with allogenic transplants to prevent graft rejection, might help protect cells, but no current therapies reliably stop myelin destruction.

Despite this, we believe earlier intervention might well have the best prospect of success. Spontaneous remyelination appears to occur maximally in acute inflammatory lesions, ${ }^{5,28}$ suggesting an optimally propitious environment. Indeed, some suggest that anti-inflammatory drugs $^{29}$ or the suppression of inflammation in general ${ }^{30}$ may impair myelin regeneration.

The clinical impact of the accumulating axon loss in secondary progressive disease $e^{2,31}$ provides a more potent reason for earlier remyelinating intervention. Quite apart from the futility of attempting to remyelinate axons long since departed, recent findings indicate that changes in the cell surface expression of various molecules (e.g., polysialic acid-neural cell adhesion molecule) in chronically demyelinated axons actively inhibit myelination. ${ }^{32}$ Also apparent is a profound inhibitory effect on remyelinating glia of chronic astrocytosis, ${ }^{33}$ a key feature of the chronically demyelinated lesion. These considerations all seriously mitigate against deferred intervention but, in addition, the underlying cause of axon loss also must be considered.

The course of secondary progression-and by implication, of axon loss-appears to be influenced neither by early inflammatory disease activity ${ }^{34-36}$ nor, sadly, by 
even the most profound immune suppressant or antiinflammatory treatments. These and other observations have fueled the hypothesis that progressive axonal damage is (at least in part) a consequence of persistent myelin loss. $2,37,38$ Pathological studies have indicated that chronic axon loss does not correlate with inflammatory cell infiltrate, tumor necrosis factor (TNF) expression, nitric oxide expression, or demyelinating activity, but is related to the overall extent of established myelin loss. ${ }^{34,36}$ It is seen in lesions which are demyelinated but which exhibit sparse or no inflammation, but is rare in remyelinated lesions. ${ }^{36}$ Demyelination-induced axon loss might occur by several possible mechanisms: directly, through the loss of oligodendrocyte-derived trophic support, ${ }^{37,39,40}$ or sustained demyelination-induced conduction block and electrical silence, ${ }^{41}$ or indirectly through increased vulnerability of the exposed axon to injurious agents. ${ }^{42} \mathrm{~A}$ further important driver for early intervention thus emerges: the restoration of a normal oligodendroglial environment to sustain (previously demyelinated) axons. Therefore, the earlier the intervention, the greater the potential gain.

\section{The site of implantation}

Clearly, multiple inoculations of cells into widely distributed lesions in the brain and spinal cord of patients with MS is unrealistic. What should not be overlooked, however, is that many plaques are clinically silent, while a disproportionate degree of disability frequently emanates from a few critical lesions in eloquent areas. Thus, implantation into a very small number of carefully selected lesions, for example, the optic nerves, the spinal cord, or the superior cerebellar peduncle, could yield a useful therapeutic dividend. ${ }^{43}$

A more global myelin repair strategy, applicable not only for multiple sclerosis but also for the significantly rarer group of patients with inherited disorders of myelin metabolism, however, is not impossible to foresee. Transplanted cells would need to be encouraged to migrate widely, as occurs during development. Supplementing cellular transplantation with growth factor infusions ${ }^{44}$ cotransplantation with growth factor-secreting cells, ${ }^{45}$ and suppressing molecules that inhibit migration $^{33,46}$ have all been tried experimentally, with limited success. An alternative approach would exploit both the circulation of the brain and the blood-brain barrier disruption present at sites of active inflammation to disseminate and deliver cells, relying on the tropism of certain reparative cells for diseased tissue, as discussed below (in relation to bone marrow-derived and other adult stem cells).

\section{Monitoring success or otherwise}

At present, the MRI detection of new myelin is not reliably feasible, but new techniques continue to emerge, of which magnetization transfer contrast is the strongest candidate for imaging remyelination. ${ }^{47}$ Magnetic resonance spectroscopy measurement of $\mathrm{N}$-acetyl-aspartate levels might offer means of assessing any impact on local neuron/axon survival. ${ }^{48,49}$ Using paramagnetic particles to label cells before transplantation, enabling their dispersion to be tracked by $\mathrm{MRI}^{50-52}$ has promise, although from a safety perspective, even the most trivial manipulation of cells before implantation would be better avoided. Furthermore, graft survival cannot be inferred from migration, since dead cells remain visible, ${ }^{50}$ and this method not only fails to show new myelin formation but may also impair the ability of other MR modalities to do so.

Serial neurophysiology may prove valuable, and monitoring conduction times may provide evidence of returning saltatory conduction in the targeted pathway(s). The optic nerve has particular advantages in this respect, but various approaches to more generalized neurophysiological assessment have been described and may prove useful for any intervention aimed at multifocal or more diffuse myelin repair. ${ }^{53}$

Finally, remyelination without clinical improvement would be a hollow victory, so robust and reproducible methods of clinical assessment need to be applied $a b$ initio. Specific clinical outcome measures of function, disability, and handicap must be adopted and tailored for each type of intervention. Ultimately, success will need to be measured using properly designed clinical trials, in which clinical outcomes should be paramount. Considerable advances in clinical scale design have improved physical and functional measurement in multiple sclerosis ${ }^{54}$ so that the tools for assessing clinical outcome, on which remyelination therapies must stand or fall, are becoming available.

\section{Choice of reparative cell}

Cells of the oligodendrocyte lineage. Oligodendrocytes are the most obvious candidates. These are the cells lost in multiple sclerosis, and it is their normal function to myelinate the CNS. Immature oligodendrocytes and oligodendrocyte precursors are found in fresh lesions ${ }^{5-60}$ and are generally considered responsible for the majority of spontaneous remyelination. ${ }^{61-64}$ Consideration of the stage within the oligodendrocyte lineage optimal for transplantation is important. Although some studies have suggested that mature differentiated oligodendrocytes are useful myelinating cells, ${ }^{10}$ the majority view is that mitotic ${ }^{65}$ and migratory ${ }^{14,66,67}$ capacities are vital prerequisites for successful remyelination, and that postmitotic oligodendrocytes, lacking these competencies, do not readily recapitulate their development to form myelin sheaths again. ${ }^{14,68,69}$

Despite their motility, oligodendrocyte progenitors show poor survival and migration when implanted into normal white matter, although they are able to populate 
and remyelinate when injected into, or very close to, lesioned tissue. ${ }^{70}$ By contrast, these cells survive well in $\mathrm{x}$-irradiated tissue, which depletes endogenous progenitors. ${ }^{71}$ Part of this increased survival may reflect competition between endogenous and implanted cells for survival factors, because progenitor numbers increase with increased availability of platelet-derived growth factor $(\mathrm{PDGF})^{72}$ or glial growth factor 2 (GGF2). ${ }^{73}$ The possibility of improving graft survival and proliferation by the use of growth factors has been explored in vivo with some success ${ }^{45}$ but this introduces a further complication in developing clinical therapy.

A further difficulty of "using" oligodendrocyte progenitors is that investigations of human CNS glia have consistently demonstrated significant biological differences from rodent cells, so that data concerning rodent oligodendrocyte progenitor cells (OPCs) cannot be directly extrapolated to human glia. Early studies identified glia similar to the rodent OPCs in cultures derived from the fetal human $\mathrm{CNS}^{74}$; these cells can synthesize myelin in the dysmyelinated rodent CNS, even after cryopreservation. ${ }^{75}$ Initial studies of the more recently identified adult human oligodendrocyte progenitors ${ }^{76-78}$ suggested a very limited capacity for remyelination (in the irradiated rodent spinal cord) ${ }^{79}$ However, elegant methods for selection of these cells (for experimental purposes) from samples of human white matter have since been perfect$\mathrm{ed}^{80}$ and, interestingly, very recent comparative studies suggest that adult human CNS-derived oligodendrocyte progenitors have a significantly greater remyelinating capacity than their fetal counterparts. ${ }^{81}$

Schwann cells. Perhaps surprisingly, Schwann cells make a significant contribution to endogenous myelin repair in multiple sclerosis, particularly in the spinal cord. ${ }^{6,82,83}$ Experimental methods have been established for preparing cultures of Schwann cells from adult peripheral nerve biopsies and for purifying and expanding the cells in vitro to generate large populations of Schwann cells. ${ }^{84,85}$ When so purified, human Schwann cells successfully lay down new myelin in the mouse ${ }^{86}$ and the rat spinal cord. ${ }^{87,88}$

Autologous Schwann cell harvesting from peripheral nerve biopsy, expansion in vitro, and transplantation into patients with multiple sclerosis offers the considerable attractions of relative ease of availability, and the avoidance of rejection. Furthermore, by contrast with oligodendrocyte-established new myelin, Schwann cells and their myelin sheaths should be resistant to continuing disease-related immunological attack. Firm evidence is required, however, that expanded human Schwann cells do not form tumors in vivo, a hazard described when rodent Schwann cells immortalized by growth factor expansion were transplanted ${ }^{89}$; unpurified preparations of human peripheral nerve cells result in substantial fibroblast overgrowth with axon destruction ${ }^{87}$; this obviously

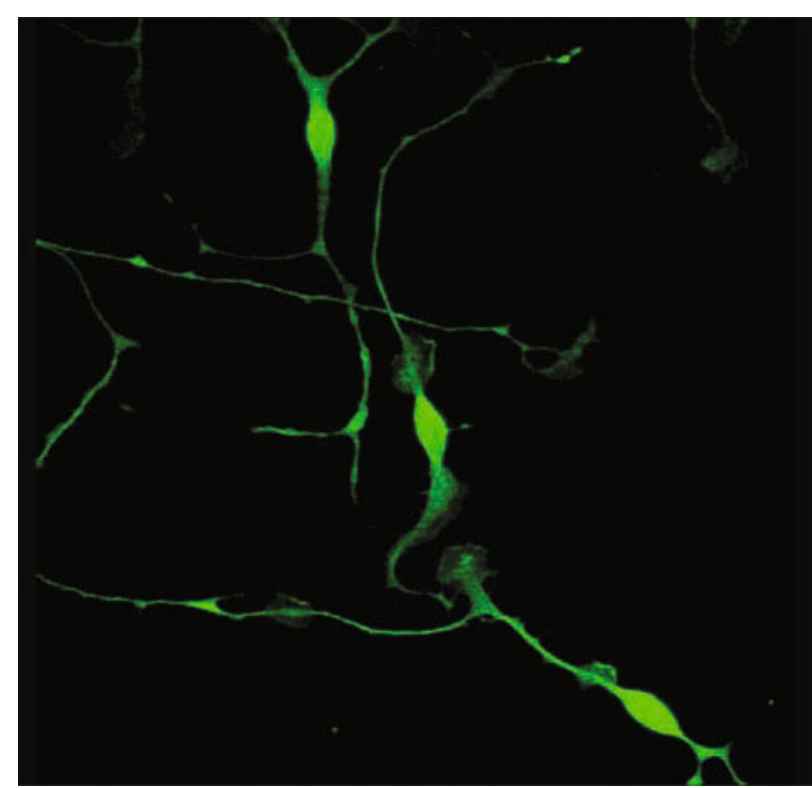

FIG. 2. Cultured Schwann cells, stained with $\mathrm{S} 100$.

presents an imposing barrier to the clinical application of Schwann cell transplants. The apparent inhibitory effect of astrocytes on Schwann cell-mediated CNS remyelination $^{90-92}$ represents another potential problem for the use of Schwann cells in remyelination therapy (FIG. 2).

Olfactory glia. OECs ensheath the axons emanating from olfactory epithelial neurons that penetrate the olfactory bulb of the CNS (FIG. 3). They are found in the olfactory bulb, nerves, and epithelium. Normally, OECs are nonmyelinating, but rodent OECs assume a myelinating phenotype closely resembling that of Schwann cells when transplanted into lesions containing demyelinated axons. ${ }^{20,21}$ The ability of OECs to promote CNS axon regeneration and ensheath and myelinate demyelinated axons has led to considerable interest in olfactory glia in the field of CNS repair. ${ }^{93}$

One of the potential advantages of OECs over Schwann cells relates to their relationship with astro-

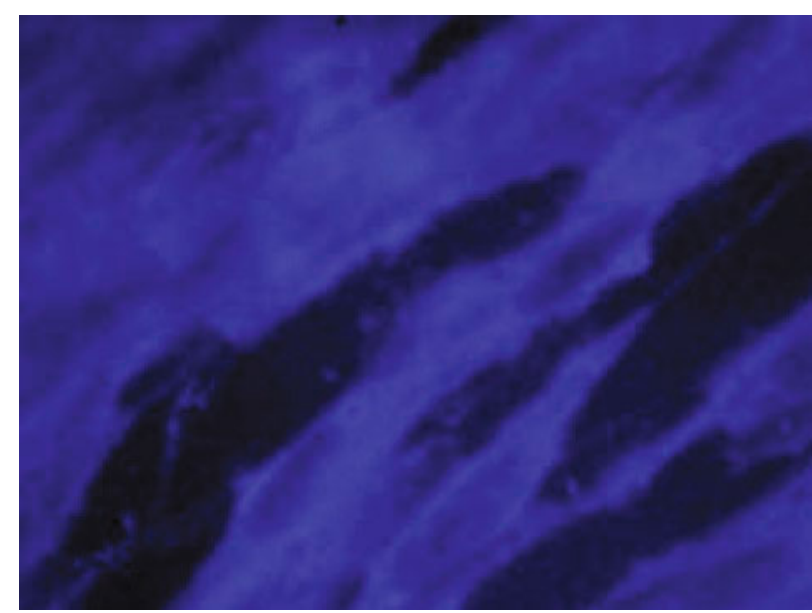

FIG. 3. Adult human olfactory glia in vitro. 
cytes. In health, OECs coexist alongside astrocytes within the olfactory bulb, whereas in experimentally demyelinated lesions, OECs can (in contrast to Schwann cells) ensheath and myelinate axons unimpeded by the astrocytic environment. ${ }^{20}$ In vitro, rodent OECs migrate far more successfully over astrocytes than Schwann cells. ${ }^{94}$ Human OECs, like rodent OECs, are capable of remyelination following transplantation into the demyelinated rodent spinal cord. ${ }^{95,96}$

Stem cells. There is general agreement that stem cells have enormous therapeutic potential, perhaps particularly for the treatment of neurodegenerative disease. ${ }^{97-100}$ To date, most studies have concentrated on using embryonic tissue as a source of stem cells, and certainly rodent embryonic stem cells possess considerable remyelinating potential. $^{22}$ However, to develop therapies would obviously require the dissection of human embryos as the stem cell source, and this raises significant practical, immunological, and ethical concerns. One serious risk is that of teratoma formation ${ }^{101}$; removing this capacity from embryonic stem cells with absolute success may pose considerable problems. In addition, the emergence of significant chromosomal abnormalities in cultured human embryonic stem cells raises further concerns about their safe use. ${ }^{102}$ The problem of rejection would also have to be circumvented. Although this might be overcome using stem cells from embryos cloned (by cell nuclear transfer) from individual putative recipients (recently legalized uniquely in the United Kingdom), the implication that every patient requiring a transplant would first have to be cloned seems quite unrealistic and would not bypass the major ethical difficulties associated with the use of human embryonic material.

These problems have helped stimulate the largely successful search for alternative sources of stem cells. ${ }^{103}$ There is increasing evidence that adult stem cells have a greater capacity to differentiate into a wider range of cell types than previously anticipated, and the use of adult stem cells, particularly autologous cells would avoid many of the difficulties associated with embryonic stem cells. ${ }^{103-106}$

It is now clear that neural stem cells are present in the adult rodent brain ${ }^{107}$; large numbers of oligodendrocyte lineage cells can be generated using neurosphere/oligosphere techniques, which, upon transplantation, successfully remyelinate axons. Neural stem cells are also present in the adult human brain (FIG. 4). ${ }^{108}$ Recently, it has been reported that adult CNS-derived rodent stem cells will repair multifocal demyelinating lesions (in experimental allergic encephalomyelitis-affected rodents) even after intravenous delivery. ${ }^{24}$

Bone marrow-derived stem cells (FIG. 5) are also capable of homing to damaged tissue(s) from the circulation, ${ }^{109,110}$ and this tropism includes movement toward injured CNS tissue. ${ }^{111,112}$ It is now beyond doubt that adult bone marrow harbors a subpopulation of poten-

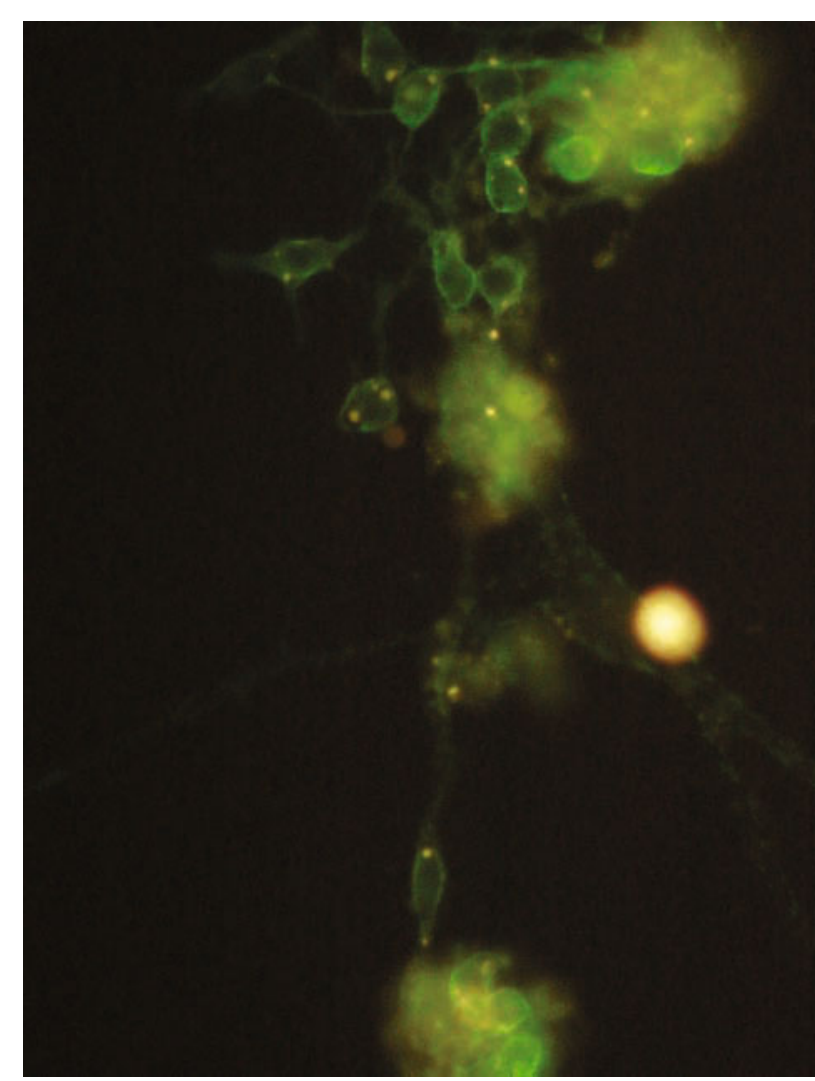

FIG. 4. Adult human brain-derived neural stem cells differentiated into oligodendrocyte progenitors and stained with NG2.

tially highly proliferative stem cells, ${ }^{106,112-120}$ whose differentiation capacity includes glial cells and neurones. $^{121-124}$ Transplant studies in rodents have confirmed the ability of bone marrow-derived cells to express neural phenotypes in the CNS of recipients. Directly or peripherally injected bone marrow-derived cells will repair damage, often with demonstrable functional as well as anatomical recovery, in rodent models of traumatic, degenerative, and ischemic CNS damage. ${ }^{12,125-131}$ Remyelination is reported not only after

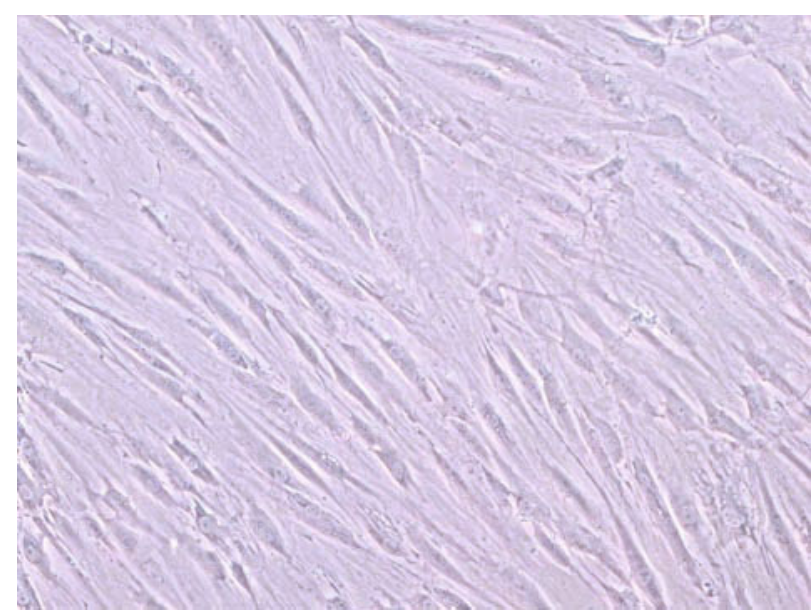

FIG. 5. Adult human mesenchymal stem cells in culture. 
direct injection into lesions, ${ }^{27,132}$ but also, in more recent studies, after peripheral injection. ${ }^{26}$

These properties, together with their easy accessibility, ethical robustness, and significant track history in the treatment of hematological disease makes bone marrow cells ideal candidates for use in cellular therapies for CNS disease. Further elucidation of the mechanisms involved may allow for mobilization of endogenous cells, perhaps even obviating the need for transplantation.

The possibility has been raised that cell fusion of bone marrow-derived cells with host cells provides an alternative explanation for apparent transdifferentiation. ${ }^{133,134}$ However, cell fusion cannot explain the extensive in vitro data indicating multipotentiality (see above). In vivo studies confirm transdifferentiation without fusion in a variety of tissues. ${ }^{135-137}$ Furthermore, from a pragmatic perspective, fusion may simply be part of the means by which bone marrow-derived stem cells stimulate successful regeneration ${ }^{138}$; bone marrow-host cell fusion in a liver disease model ${ }^{133,134}$ occurs in the context of metabolic rescue by transplanted cells with functional liver repair and survival of treated animals. ${ }^{139}$ Recent studies indicate that polyploidy is in fact a far more common phenomenon that previously realized; the possible occurrence of fusion does not necessarily imply diminished regenerative capacity in a putative reparative cell. ${ }^{140,141}$

\section{CONCLUSION}

We believe that cellular therapy holds considerable promise for patients with demyelinating disease, and are optimistic that this promise may begin to be realized within the relatively near future. We would caution against expecting reports of great benefit from trials restricted to recruiting patients with chronic disease who already have established stable (or progressive) disability, in whom one might predict a minimal response. Nevertheless, we look forward to the time when eligibility for cellular therapy trials will be less restrictive and, in the interim, continue to accrue the safety data and basic understanding of the mechanisms involved that will make this a reality.

Acknowledgments: We thank the United Kingdom Multiple Sclerosis Society, The Patrick Berthoud Charitable Trust, and The Ipsen Trust for support. The Burden Chair of Clinical Neurosciences is supported by The Burden Trust.

\section{REFERENCES}

1. Smith KJ, McDonald WI. The pathophysiology of multiple sclerosis: the mechanisms underlying the production of symptoms and the natural history of the disease. Philos Trans R Soc Lond B Biol Sci 354:1649-1673, 1999.

2. Bjartmar C, Trapp BD. Axonal and neuronal degeneration in multiple sclerosis: mechanisms and functional consequences. Curr Opin Neurol 14:271-278, 2001.
3. Lassmann H, Bruck W, Lucchinetti CF, Rodriguez M. Remyelination in multiple sclerosis. Mult Scler 3:133-136, 1997.

4. Prineas JW, Connell F. Remyelination in multiple sclerosis. Ann Neurol 5:22-31, 1979.

5. Raine CS, Wu E. Multiple sclerosis: Remyelination in acute lesions. J Neuropathol Exp Neurol 52:199-204, 1993.

6. Ludwin S. Remyelination in the central nervous system and in the peripheral nervous system. Adv Neurol 47:215-254, 1988.

7. Harrison BM. Remyelination by cells introduced into a stable demyelinating lesion in the central nervous system. J Neurol Sci 46:63-81, 1980.

8. Baron-Van Evercooren A, Avellana-Adalid V, Lachapelle F, Liblau R. Schwann cell transplantation and myelin repair of the CNS. Mult Scler 3:157-161, 1997.

9. Honmou O, Felts PA, Waxman SG, Kocsis JD. Restoration of normal conduction properties in demyelinated spinal cord axons in the adult rat by transplantation of exogenous Schwann cells. J Neurosci 16:3199-3208, 1996.

10. Duncan ID, Paino C, Archer DR, Wood PM. Functional capacities of transplanted cell-sorted adult oligodendrocytes. Dev Neurosci 14:114-122, 1992.

11. Franklin RJM, Blakemore WF. Transplanting oligodendrocyte progenitors into the adult CNS. J Anat 190:23-33, 1997.

12. Groves AK, Barnett SC, Franklin RJM, Crang AJ, Mayer M, Blakemore WF et al. Repair of demyelinated lesions by transplantation of purified O-2A progenitor cells. Nature 362:453$455,1993$.

13. Rosenbluth J. Glial transplantation in the treatment of myelin loss or deficiency. In: The neurobiology of disease: contributions from neuroscience to clinical neurology (Bostock H, Kirkwood PA, Pullen AH, eds), pp 124-148. Cambridge: Cambridge University Press, 1996.

14. Warrington AE, Barbarese E, Pfeiffer SE. Differential myelinogenic capacity of specific developmental stages of the oligodendrocyte lineage upon transplantation into hypomyelinating hosts. J Neurosci Res 34:1-13, 1993.

15. Kocsis JD. Restoration of function by glial cell transplantation into demyelinated spinal cord. J Neurotrauma 16:695-703, 1999.

16. Barnett SC, Franklin RJM, Blakemore WF. In vitro and in vivo analysis of a rat bipotential O-2A progenitor cell line containing the temperature-sensitive mutant gene of the SV40 large T antigen. Eur J Neurosci 5:1247-1260, 1993.

17. Tontsch U, Archer DR, Dubois-Dalcq M, Duncan ID. Transplantation of an oligodendrocyte cell line leading to extensive myelination. Proc Natl Acad Sci USA 91:11616-11620, 1994.

18. Utzschneider DA, Archer DR, Kocsis JD, Waxman SG, Duncan ID. Transplantation of glial cells enhances action potential conduction of amyelinated spinal cord axons in the myelin-deficient rat. Proc Natl Acad Sci USA 91:53-57, 1994.

19. Jeffery ND, Crang AJ, O'Leary MT, Hodge SJ, Blakemore WF. Behavioural consequences of oligodendrocyte progenitor cell transplantation into experimental demyelinating lesions in the rat spinal cord. Eur J Neurosci 11:1508-1514, 1999.

20. Franklin RJM, Gilson JM, Franceschini IA, Barnett SC. Schwann cell-like myelination following transplantation of an olfactory bulb-ensheathing cell-line into areas of demyelination in the adult CNS. Glia 17:217-224, 1996.

21. Imaizumi T, Lankford KL, Waxman SG, Greer CA, Kocsis JD. Transplanted olfactory ensheathing cells remyelinate and enhance axonal conduction in the demyelinated dorsal columns of the rat spinal cord. J Neurosci 18:6176-6185, 1998.

22. Brustle O, Jones KN, Learish RD, Karram K, Choudhary K, Wiestler OD et al. Embryonic stem cell-derived glial precursors: a source of myelinating transplants. Science 285:754-756, 1999.

23. Zhang SC, Ge B, Duncan ID. Adult brain retains the potential to generate oligodendroglial progenitors with extensive myelination capacity. Proc Natl Acad Sci USA 96:4089-4094, 1999.

24. Pluchino S, Quattrini A, Brambilla E, Gritti A, Salani G, Dina G et al. Injection of adult neurospheres induces recovery in a chronic model of multiple sclerosis. Nature 422:688-694, 2003.

25. Rogister B, Ben Hur T, Dubois-Dalcq M. From neural stem cells to myelinating oligodendrocytes. Mol Cell Neurosci 14:287-300, 1999. 
26. Akiyama Y, Radtke C, Honmou O, Kocsis JD. Remyelination of the spinal cord following intravenous delivery of bone marrow cells. Glia 39:229-236, 2002.

27. Sasaki M, Honmou O, Akiyama Y, Uede T, Hashi K, Kocsis JD. Transplantation of an acutely isolated bone marrow fraction repairs demyelinated adult rat spinal cord axons. Glia 35:26-34, 2001.

28. Prineas JW, Barnard RO, Kwon EE, Sharer LR, Cho ES. Multiple sclerosis: remyelination of nascent lesions. Ann Neurol 33:137151, 1993.

29. Smith PM, Franklin RJ. The effect of immunosuppressive protocols on spontaneous CNS remyelination following toxin-induced demyelination. J Neuroimmunol 119:261-268, 2001.

30. Cuzner ML, Loughlin AJ, Mosley K, Woodroofe MN. The role of microglia macrophages in the processes of inflammatory demyelination and remyelination. Neuropathol Appl Neurobiol 20:200-201, 1994.

31. Bjartmar C, Kidd G, Mork S, Rudick R, Trapp BD. Neurological disability correlates with spinal cord axonal loss and reduced $\mathrm{N}$-acetyl aspartate in chronic multiple sclerosis patients. Ann Neurol 48:893-901, 2000.

32. Charles P, Hernandez MP, Stankoff B, Aigrot MS, Colin C, Rougon $G$ et al. Negative regulation of central nervous system myelination by polysialylated-neural cell adhesion molecule. Proc Natl Acad Sci USA 97:7585-7590, 2000.

33. Fawcett JW, Asher RA. The glial scar and central nervous system repair. Brain Res Bull 49:377-391, 1999.

34. Bitsch A, Schuchardt J, Bunkowski S, Kuhlmann T, Bruck W. Acute axonal injury in multiple sclerosis. Correlation with demyelination and inflammation. Brain 123:1174-1183, 2000.

35. Confavreux C, Vukusic S, Moreau T, Adeleine P. Relapses and progression of disability in multiple sclerosis. $N$ Engl $J$ Med 343:1430-1438, 2000.

36. Kornek B, Storch MK, Weissert R, Wallstroem E, Stefferl A, Olsson $\mathrm{T}$ et al. Multiple sclerosis and chronic autoimmune encephalomyelitis: a comparative quantitative study of axonal injury in active, inactive, and remyelinated lesions. Am J Pathol 157:267-276, 2000.

37. Wilkins A, Majed H, Layfield R, Compston A, Chandran S. Oligodendrocytes promote neuronal survival and axonal length by distinct intracellular mechanisms: a novel role for oligodendrocyte-derived glial cell line-derived neurotrophic factor. J Neurosci 23:4967-4974, 2003.

38. Scolding N, Franklin R. Axon loss in multiple sclerosis. Lancet 352:340-341, 1998.

39. Meyer-Franke A, Kaplan MR, Pfrieger FW, Barres BA. Characterization of the signaling interactions that promote the survival and growth of developing retinal ganglion cells in culture. Neuron 15:805-819, 1995.

40. Griffiths I, Klugmann M, Anderson T, Yool D, Thomson C, Schwab MH et al. Axonal swellings and degeneration in mice lacking the major proteolipid of myelin. Science 280:1610-1613, 1998.

41. Lipton SA. Blockade of electrical-activity promotes the death of mammalian retinal ganglion-cells in culture. Proc Natl Acad Sci USA 83:9774-9778, 1986.

42. Raine CS, Cross AH. Axonal dystrophy as a consequence of long-term demyelination. Lab Invest 60:714-725, 1989.

43. Compston DAS. Remyelination of the central nervous system. Mult Scler 1:388-392, 1996.

44. Fricker-Gates RA, Winkler C, Kirik D, Rosenblad C, Carpenter MK, Bjorklund A. EGF infusion stimulates the proliferation and migration of embryonic progenitor cells transplanted in the adult rat striatum. Exp Neurol 165:237-247, 2000.

45. Milward EA, Zhang SC, Zhao M, Lundberg C, Ge B, Goetz BD et al. Enhanced proliferation and directed migration of oligodendroglial progenitors co-grafted with growth factor-secreting cells. Glia 32:264-270, 2000.

46. Schnadelbach O, Blaschuk OW, Symonds M, Gour BJ, Doherty $\mathrm{P}$, Fawcett JW. N-cadherin influences migration of oligodendrocytes on astrocyte monolayers. Mol Cell Neurosci 15:288-302, 2000 .
47. Deloire-Grassin MS, Brochet B, Quesson B, Delalande C, Dousset $\mathrm{V}$, Canioni $\mathrm{P}$ et al. In vivo evaluation of remyelination in rat brain by magnetization transfer imaging. J Neurol Sci 178:10-16, 2000.

48. Davie CA, Barker GJ, Webb S, Tofts PS, Thompson AJ, Harding $\mathrm{AE}$ et al. Persistent functional deficit in multiple sclerosis and autosomal dominant cerebellar ataxia is associated with axon loss. Brain 118:1583-1592, 1995.

49. De Stefano N, Matthews PM, Antel JP, Preul M, Francis G, Arnold DL. Chemical pathology of acute demyelinating lesions and its correlation with disability. Ann Neurol 38:901-909, 1995.

50. Bulte JW, Zhang S, van Gelderen P, Herynek V, Jordan EK, Duncan ID et al. Neurotransplantation of magnetically labeled oligodendrocyte progenitors: magnetic resonance tracking of cell migration and myelination. Proc Natl Acad Sci USA 96:15256$15261,1999$.

51. Franklin RJ, Blaschuk KL, Bearchell MC, Prestoz LL, Setzu A, Brindle $\mathrm{KM}$ et al. Magnetic resonance imaging of transplanted oligodendrocyte precursors in the rat brain. NeuroReport 10:3961-3965, 1999.

52. Lewin M, Carlesso N, Tung CH, Tang XW, Cory D, Scadden DT et al. Tat peptide-derivatized magnetic nanoparticles allow in vivo tracking and recovery of progenitor cells. Nat Biotechnol $18: 410-414,2000$

53. Leocani L, Medaglini S, Comi G. Evoked potentials in monitoring multiple sclerosis. Neurol Sci 21[Suppl 2]:S889-S891, 2000.

54. Hobart J, Lamping D, Fitzpatrick R, Riazi A, Thompson A. The multiple sclerosis impact scale (MSIS-29): a new patient-based outcome measure. Brain 124:962-973, 2001.

55. Raine CS, Scheinberg L, Waltz JM. Multiple sclerosis. Oligodendrocyte survival and proliferation in an active established lesion. Lab Invest 45:534-546, 1981.

56. Prineas JW, Kwon EE, Goldenberg PZ. Multiple sclerosis: oligodendrocyte proliferation and differentiation in fresh lesions. Lab Invest 61:489-503, 1989.

57. Scolding NJ, Franklin RJM, Stevens S, Heldin CH, Compston DAS, Newcombe J. Oligodendrocyte progenitors are present in the normal adult human CNS and in the lesions of multiple sclerosis. Brain 121:2221-2228, 1998.

58. Chang A, Nishiyama A, Peterson J, Prineas J, Trapp BD. NG2positive oligodendrocyte progenitor cells in adult human brain and multiple sclerosis lesions. J Neurosci 20:6404-6412, 2000.

59. Wolswijk G. Chronic stage multiple sclerosis lesions contain a relatively quiescent population of oligodendrocyte precursor cells. J Neurosci 18:601-609, 1998.

60. Maeda Y, Solanky M, Menonna J, Chapin J, Li W, Dowling P. Platelet-derived growth factor-alpha receptor-positive oligodendroglia are frequent in multiple sclerosis lesions. Ann Neurol 49:776-785, 2001.

61. Carroll WM, Jennings AR. Early recruitment of oligodendrocyte precursors in CNS demyelination. Brain 117:563-578, 1994.

62. Duncan ID, Grever WE, Zhang SC. Repair of myelin disease: strategies and progress in animal models. Mol Med Today 3:554561, 1997.

63. Wolswijk G. Oligodendrocyte survival, loss and birth in lesions of chronic-stage multiple sclerosis. Brain 123:105-115, 2000.

64. Scolding NJ, Franklin RJM. Remyelination in demyelinating disease. Bailleres Clin Neurol 6:525-548, 1997.

65. Blakemore WF, Keirstead HS. The origin of remyelinating cells in the central nervous system. J Neuroimmunol 98:69-76, 1999.

66. Baronvanevercooren A, Avellanaadalid V, Benyouneschennoufi A, Gansmuller A, Naitoumesmar B, Vignais L. Cell-cell interactions during the migration of myelin-forming cells transplanetd in the demyelinated spinal cord. Glia 16:147-164, 1996.

67. Kiernan BW, ffrench-Constant C. Oligodendrocyte precursor (O-2A progenitor cell) migration; a model system for the study of cell migration in the developing central nervous system. Dev Suppl 119:219-225, 1993.

68. Archer DR, Cuddon PA, Lipsitz D, Duncan ID. Myelination of the canine central nervous system by glial cell transplantation: a model for repair of human myelin disease. Nat Med 3:54-59, 1997. 
69. Kierstead HS, Blakemore WF. Identification of post-mitotic oligodendrocytes incapable of remyelination within the demyelinated adult spinal cord. J Neuropathol Exp Neurol 56:1191-1201, 1997.

70. Franklin RJM, Bayley SA, Blakemore WF. Transplanted CG4 cells (an oligodendrocyte progenitor cell line) survive, migrate, and contribute to repair of areas of demyelination in X-irradiated and damaged spinal cord but not in normal spinal cord. Exp Neurol 137:263-276, 1996.

71. Hinks GL, Chari DM, O'Leary MT, Zhao C, Keirstead HS, Blakemore WF et al. Depletion of endogenous oligodendrocyte progenitors rather than increased availability of survival factors is a likely explanation for enhanced survival of transplanted oligodendrocyte progenitors in X-irradiated compared to normal CNS. Neuropathol Appl Neurobiol 27:59-67, 2001.

72. Barres BA, Hart IK, Coles HS, Burne JF, Voyvodic JT, Richardson WD et al. Cell death and control of cell survival in the oligodendrocyte lineage. Cell 70:31-46, 1992.

73. Noel F, Raju U, Happel E, Marchionni MA, Tofilon PJ. X-irradiation-induced loss of O-2A progenitor cells in rat spinal cord is inhibited by implants of cells engineered to secrete glial growth factor 2. NeuroReport 10:535-540, 1999.

74. Kennedy PGE, Fok-Seang J. Studies on the development, antigenic phenotype and function of human glial cells in tissue culture. Brain 109:1261-1277, 1986.

75. Seilhean D, Gansmuller A, Baronvan Evercooren A, Gumpel M, Lachapelle F. Myelination by transplanted human and mouse central nervous system tissue after long-term cryopreservation. Acta Neuropathologica 91:82-88, 1996.

76. Prabhakar S, D'Souza S, Antel JP, McClaurin JA, Schipper HM, Wang E. Phenotypic and cell-cycle properties of human oligodendrocytes in-vitro. Brain Res 672:159-169, 1995.

77. Armstrong RC, Dorn HH, Kufta CV, Friedman E, Dubois-Dalcq ME. Pre-oligodendrocytes from adult human CNS. J Neurosci 12:1538-1547, 1992.

78. Scolding NJ, Rayner PJ, Sussman J, Shaw C, Compston DAS. A proliferative adult human oligodendrocyte progenitor. NeuroReport 6:441-445, 1995.

79. Targett MP, Sussman J, Scolding N, O'Leary MT, Compston DAS, Blakemore WF. Failure to achieve remyelination of demyelinated rat axons following transplantation of glial cells obtained from the adult human brain. Neuropathol Appl Neurobiol 22: 199-206, 1996.

80. Roy NS, Wang S, Harrison-Restelli C, Benraiss A, Fraser RA, Gravel $\mathrm{M}$ et al. Identification, isolation, and promoter-defined separation of mitotic oligodendrocyte progenitor cells from the adult human subcortical white matter. J Neurosci 19:9986-9995, 1999.

81. Windrem MS, Nunes MC, Rashbaum WK, Schwartz TH, Goodman RA, McKhann G et al. Fetal and adult human oligodendrocyte progenitor cell isolates myelinate the congenitally dysmyelinated brain. Nat Med 10:93-97, 2004.

82. Ogata J, Feigin I. Schwann cells and regenerated peripheral myelin in multiple sclerosis: an ultrastructural study. Neurology 25:713-716, 1975.

83. Itoyama Y, Webster HD, Richardson-EP J, Trapp BD. Schwann cell remyelination of demyelinated axons in spinal cord multiple sclerosis lesions. Ann Neurol 14:339-346, 1983.

84. Morrissey TK, Levi AD, Nuijens A, Sliwkowski MX, Bunge RP. Axon-induced mitogenesis of human Schwann cells involves heregulin and p185erbB2. Proc Natl Acad Sci USA 92:1431$1435,1995$.

85. Rutkowski JL, Kirk CJ, Lerner MA, Tennekoon GI. Purification and expansion of human schwann cells in vitro. Nat Med 1:8083, 1995.

86. Levi ADO, Bunge RP. Studies of myelin formation after transplantation of human Schwann cells into the severe combined immunodeficient mouse. Exp Neurol 130:41-52, 1994.

87. Brierley CM, Crang AJ, Iwashita Y, Gilson JM, Scolding NJ, Compston DA et al. Remyelination of demyelinated CNS axons by transplanted human schwann cells: the deleterious effect of contaminating fibroblasts. Cell Transplant 10:305-315, 2001.
88. Kohama I, Lankford KL, Preiningerova J, White FA, Vollmer TL, Kocsis JD. Transplantation of cryopreserved adult human Schwann cells enhances axonal conduction in demyelinated spinal cord. J Neurosci 21:944-950, 2001.

89. Langford LA, Porter S, Bunge RP. Immortalized rat Schwann cells produce tumours in vivo. J Neurocytol 17:521-529, 1988.

90. Franklin RJM, Blakemore WF. Requirements for Schwann cell migration within CNS environments: a viewpoint. Int J Dev Neurosci 11:641-649, 1993.

91. Harrison B. Schwann cell and oligodendrocyte remyelination in lysolecithin-induced lesions in irradiated rat spinal cord. J Neurol Sci 67:143-159, 1985.

92. Woodruff RH, Franklin RJ. Demyelination and remyelination of the caudal cerebellar peduncle of adult rats following stereotaxic injections of lysolecithin, ethidium bromide, and complement/ anti-galactocerebroside: a comparative study. Glia 25:216-228, 1999.

93. Franklin RJ, Barnett SC. Olfactory ensheathing cells and CNS regeneration: the sweet smell of success? Neuron 28:15-18, 2000.

94. Lakatos A, Franklin RJ, Barnett SC. Olfactory ensheathing cells and Schwann cells differ in their in vitro interactions with astrocytes. Glia 32:214-225, 2000.

95. Barnett SC, Alexander CL, Iwashita Y, Gilson JM, Crowther J, Clark L et al. Identification of a human olfactory ensheathing cell that can effect transplant-mediated remyelination of demyelinated CNS axons. Brain 123:1581-1588, 2000.

96. Kato T, Honmou O, Uede T, Hashi K, Kocsis JD. Transplantation of human olfactory ensheathing cells elicits remyelination of demyelinated rat spinal cord. Glia 30:209-218, 2000.

97. Bjorklund A. Cell replacement strategies for neurodegenerative disorders. Novartis Found Symp 231:7-20, 2000.

98. Cao Q, Benton RL, Whittemore SR. Stem cell repair of central nervous system injury. J Neurosci Res 68:501-510, 2002.

99. Park KI, Ourednik J, Ourednik V, Taylor RM, Aboody KS, Auguste KI et al. Global gene and cell replacement strategies via stem cells. Gene Ther 9:613-624, 2002.

100. Weissman IL. Translating stem and progenitor cell biology to the clinic: barriers and opportunities. Science 287:1442-1446, 2000.

101. Björklund LM, Sanchez-Pernaute R, Chung S et al. Embryonic stem cells develop into functional dopaminergic neurons after transplantation in a Parkinson rat model. Proc Natl Acad Sci USA 99:2344-2349, 2002.

102. Draper JS, Smith K, Gokhale P, Moore HD, Maltby E, Johnson J et al. Recurrent gain of chromosomes $17 \mathrm{q}$ and 12 in cultured human embryonic stem cells. Nat Biotechnol 22:53-54, 2004.

103. Scolding N. New cells from old. Lancet 357:329-330, 2001.

104. Clarke D, Frisen J. Differentiation potential of adult stem cells. Curr Opin Genet Dev 11:575-580, 2001.

105. Prockop DJ. Adult stem cells gradually come of age. Nat Biotechnol 20:791-792, 2002.

106. Poulsom R, Alison MR, Forbes SJ, Wright NA. Adult stem cell plasticity. J Pathol 197:441-456, 2002.

107. Weiss S, Dunne C, Hewson J, Wohl C, Wheatley M, Peterson AC et al. Multipotent CNS stem cells are present in the adult mammalian spinal cord and ventricular neuroaxis. J Neurosci 16 : 7599-7609, 1996.

108. Kukekov VG, Laywell ED, Suslov O, Davies K, Scheffler B, Thomas LB et al. Multipotent stem/progenitor cells with similar properties arise from two neurogenic regions of adult human brain. Exp Neurol 156:333-344, 1999.

109. Devine SM, Cobbs C, Jennings M, Bartholomew A, Hoffman R. Mesenchymal stem cells distribute to a wide range of tissues following systemic infusion into non-human primates. Blood 101: 2999-3001, 2003.

110. Korbling M, Estrov Z. Adult stem cells for tissue repair. $N$ Engl $J$ Med 349:570-582, 2003

111. Aboody KS, Brown A, Rainov NG, Bower KA, Liu S, Yang W et al. Neural stem cells display extensive tropism for pathology in adult brain: evidence from intracranial gliomas. Proc Natl Acad Sci USA 97:12846-12851, 2000.

112. Chopp M, Li Y. Treatment of neural injury with marrow stromal cells. Lancet Neurol 1:92-99, 2002. 
113. Colter DC, Sekiya I, Prockop DJ. Identification of a subpopulation of rapidly self-renewing and multipotential adult stem cells in colonies of human marrow stromal cells. Proc Natl Acad Sci USA 98:7841-7845, 2001.

114. Jiang Y, Jahagirdar BN, Reinhardt RL, Schwartz RE, Keene CD, Ortiz-Gonzalez XR et al. Pluripotency of mesenchymal stem cells derived from adult marrow. Nature 418:41-49, 2002.

115. Koc ON, Lazarus HM. Mesenchymal stem cells: heading into the clinic. Bone Marrow Transplant 27:235-239, 2001.

116. Krause DS, Theise ND, Collector MI, Henegariu O, Hwang S, Gardner $\mathrm{R}$ et al. Multi-organ, multi-lineage engraftment by a single bone marrow-derived stem cell. Cell 105:369-377, 2001.

117. Krause DS. Plasticity of marrow-derived stem cells. Gene Ther 9:754-758, 2002

118. Mezey E, Chandross KJ. Bone marrow: a possible alternative source of cells in the adult nervous system. Eur J Pharmacol 405:297-302, 2000.

119. Pittenger MF, Mackay AM, Beck SC, Jaiswal RK, Douglas R, Mosca JD et al. Multilineage potential of adult human mesenchymal stem cells. Science 284:143-147, 1999.

120. Reyes M, Lund T, Lenvik T, Aguiar D, Koodie L, Verfaille CM. Purification and ex vivo expansion of postnatal human marrow mesodermal progenitor cells. Blood 98:2615-2625, 2001.

121. Woodbury D, Schwarz EJ, Prockop DJ, Black IB. Adult rat and human bone marrow stromal cells differentiate into neurons. J Neurosci Res 61:364-370, 2000.

122. Kim BJ, Seo JH, Bubien JK, Young SO. Differentiation of adult bone marrow stem cells into neuroprogenitor cells in vitro. NeuroReport 13:1185-1188, 2002.

123. Deng W, Obrocka M, Fischer I, Prockop DJ. In vitro differentiation of human marrow stromal cells into early progenitors of neural cells by conditions that increase intracellular cyclic AMP. Biochem Biophys Res Commun 282:148-152, 2001.

124. Sanchez-Ramos J, Song S, Cardozo-Pelaez F, Hazzi C, Stedeford $\mathrm{T}$, Willing A et al. Adult bone marrow stromal cells differentiate into neural cells in vitro. Exp Neurol 164:247-256, 2000.

125. Lescaudron L, Unni D, Dunbar GL. Autologous adult bone marrow stem cell transplantation in an animal model of Huntington's disease: behavioral and morphological outcomes. Int $J$ Neurosci 113:945-956, 2003.

126. Chopp M, Zhang XH, Li Y, Wang L, Chen J, Lu D et al. Spinal cord injury in rat: treatment with bone marrow stromal cell transplantation. NeuroReport 11:3001-3005, 2000.
127. Li Y, Chen J, Wang L, Zhang L, Lu M, Chopp M. Intracerebral transplantation of bone marrow stromal cells in a 1-methyl-4phenyl-1,2,3,6-tetrahydropyridine mouse model of Parkinson's disease. Neurosci Lett 316:67-70, 2001.

128. Chen J, Li Y, Wang L, Zhang Z, Lu D, Lu M et al. Therapeutic benefit of intravenous administration of bone marrow stromal cells after cerebral ischemia in rats. Stroke 32:1005-1011, 2001.

129. Mezey E, Chandross KJ, Harta G, Maki RA, McKercher SR. Turning blood into brain: cells bearing neuronal antigens generated in vivo from bone marrow. Science 290:1779-1782, 2000.

130. Brazelton TR, Rossi FM, Keshet GI, Blau HM. From marrow to brain: expression of neuronal phenotypes in adult mice. Science 290:1775-1779, 2000.

131. Azizi SA, Stokes D, Augelli BJ, Digirolamo C, Prockop DJ. Engraftment and migration of human bone marrow stromal cells implanted in the brains of albino rats-similarities to astrocyte grafts. Proc Natl Acad Sci USA 95:3908-3913, 1998.

132. Akiyama Y, Radtke C, Kocsis JD. Remyelination of the rat spinal cord by transplantation of identified bone marrow stromal cells. J Neurosci 22:6623-6630, 2002.

133. Vassilopoulos G, Wang PR, Russell DW. Transplanted bone marrow regenerates liver by cell fusion. Nature 422:901-904, 2003.

134. Wang X, Willenbring H, Akkari Y, Torimaru Y, Foster M, Al Dhalimy $\mathrm{M}$ et al. Cell fusion is the principal source of bonemarrow-derived hepatocytes. Nature 422:897-901, 2003.

135. Tran SD, Pillemer SR, Dutra A, Barrett AJ, Brownstein MJ, Key $\mathrm{S}$ et al. Differentiation of human bone marrow-derived cells into buccal epithelial cells in vivo: a molecular analytical study. Lancet 361:1084-1088, 2003.

136. Ianus A, Holz GG, Theise ND, Hussain MA. In vivo derivation of glucose-competent pancreatic endocrine cells from bone marrow without evidence of cell fusion. J Clin Invest 111:843-850, 2003.

137. Masuya M, Drake CJ, Fleming PA, Reilly CM, Zeng H, Hill WD et al. Hematopoietic origin of glomerular mesangial cells. Blood 101:2215-2218, 2003.

138. Medvinsky A, Smith A. Stem cells: fusion brings down barriers. Nature 422:823-825, 2003.

139. Lagasse E, Connors H, Al Dhalimy M, Reitsma M, Dohse M, Osborne L et al. Purified hematopoietic stem cells can differentiate into hepatocytes in vivo. Nat Med 6:1229-1234, 2000.

140. Rice CM, Scolding NJ. Adult stem cells-reprogramming neurological repair? Lancet 364:193-199, 2004.

141. Blau HM. A twist of fate. Nature 419:437, 2002. 